\title{
Bioprocessing of Moisturized Cereals: Ruminants Crave
}

\section{Akbar Nikkhah*}

Department of Animal Sciences, University of Zanjan, Iran

The objective of this article was to practically elaborate on bioprocessing of moisturized whole and wheat grains by rumen microbes and the host ruminant. Moisturizing is a feasible cost-effective biprocessing approach towards optimizing cereal grains utilization in rumen, post-rumen gut, splanchnic tissues, and the ruminant periphery. However, despite the recent emphases on optimizing cereal use by ruminants [1-4], inadequate practical information exists to highlight the pragmatic influence of moisturizing cereals on rumen function and ruminant health and productivity.

Moistening has conventionally been utilized on poultry farms to enable effective feeding of whole cereals, especially wheat and barley, to broilers and pullets. This is particularly the case when young birds suffer from heat stress, social challenges, and feed toxicity. In essence, moisture causes grains to swallow and be more edible and palatable. As a result, depressive effects of environmental stressors and diseases on feed intake may be considerably diminished through provision of moisturized grains.

Farm experience reveal significant impacts of moisturized cereal grains on stimulating feed intake in high-producing dairy and beef cattle, especially shortly postpartum and post-feedlot entry. This article develops a recommendation to design feeding strategies to accommodate moisturized grains in commercial ruminant rations at least in part. This means that some portion of dietary grains would be delivered in moisturized form to stimulate eating of the more palatable containing diet that may provide a more synchronous release of essential nutrients to rumen microbes. These collectively can improve microbial growth and yield while increasing precursor supply to mammary glands and growing muscles.

The major questions on commercial feeding of moisturized cereals grains include whether to feed them alone as a component portion of the diet or to mix them with other feed ingredients, when during the circadian period to feed them, as what percent of the daily grain or total diet to include them, and for which groups of commercial ruminants to essentially consider feeding moisturized grains. Despite the questions, the obvious is the economical and feasible nature of moisturizing in effective bioprocessing of grains for all-size commercial and traditional ruminant farms certainly globally. A simple managemental approach such as moisturizing may be a pragmatic step towards minimizing risks of rumen malfunction and metabolic diseases that jeopardize farm economics. Initiatives must be taken to challenge the conventional farming strategies basically through simplification $[5,6]$.

As in the proverb 'when solved, puzzle becomes all easy', postmodern ruminant farming must search for the simplest most feasible approaches in firstly preventing and then solving the most complicated problems.

\section{Acknowledgments}

The Iran's Ministry of Science Research and Technology, National Elite Foundation, and University of Zanjan are gratefully acknowledged for supporting the author's global programs of optimizing science edification in the new millennium.

\section{References}

1. Nikkhah A (2014) Steam bioprocessing philosophy of cereals for ruminants: time for a new history. J Bioprocess Biotech 4: e114.

2. Nikkhah A (2010) Barley grain for ruminants: A global treasure or tragedy. $J$ Anim Sci Biotechnol 3: 22-29.

3. Nikkhah A (2014) Bioprocessing of barley for food-producing ruminants: A workable dilemma. J Bioprocess Biotech 4: e113.

4. Nikkhah A (2014) Grinding as a most economical healthy bioprocessing biotechnique of cereals for postmodern ruminants. J Bioprocess Biotech 5: e119.

5. Nikkhah A (2014) Revisiting feeding systems in postmodern ruminant agriculture: Challenging the TMR. EC Agriculture 1: 21-22.

6. Nikkhah A (2014) Bioprocessing of soft cereals for postmodern ruminants: Ascertaining decades of uncertainty. J. Bioprocess Biotech 4: e116.

*Corresponding author: Akbar Nikkhah, Chief Highly Distinguished Professor, Department of Animal Sciences, Faculty of Agricultural Sciences, University of Zanjan, Zanjan, Iran National Elite Foundation, Tehran, Iran, Tel: +98-24-350328-01; Fax: +98-24-350-332-02; E-mail: nikkhah@znu.ac.ir

Received January 24, 2015; Accepted January 25, 2015; Published January 28, 2015

Citation: Nikkhah A (2015) Bioprocessing of Moisturized Cereals: Ruminants Crave. J Bioprocess Biotech 5: e121 doi:10.4172/2155-9821.1000e121

Copyright: (C) 2015 Nikkhah A. This is an open-access article distributed under the terms of the Creative Commons Attribution License, which permits unrestricted use, distribution, and reproduction in any medium, provided the original author and source are credited. 